\title{
Passive immunization against oestradiol-17 $\beta$ and its effect on luteolysis, oestrus and ovulation in the ewe
}

\author{
R. J. Fairclough, J. F. Smith and A. J. Peterson \\ Ministry of Agriculture \& Fisheries, Research Division, \\ Ruakura Agricultural Research Centre, \\ Private Bag, Hamilton, New Zealand
}

Previous studies have suggested that the biological activity of steroid hormones can be neutralized by antibodies raised against steroid-protein hormones. Active (Ferin, Zimmering, Lieberman \& Vande Wiele, 1968) or passive (Scaramuzzi, 1975) immunization procedures have been reported. The latter method is particularly useful when studying the physiological role of hormones in the oestrous cycle when hormonal changes occur during a relatively short interval.

The preovulatory oestradiol- $17 \beta$ surge in the ewe is implicated in the induction of behavioural oestrus and ovulation (see review by Robertson, 1969), and it has also been suggested that during the later stages of the cycle oestradiol-17 $\beta$ may stimulate the production of prostaglandin F-2 $\alpha$ from the uterus (Barcikowski, Carlson, Wilson \& McCracken, 1974). Scaramuzzi (1975) demonstrated that the ability of oestradiol benzoate to induce behavioural oestrus in ovariectomized ewes was inhibited with antisera specific for oestradiol-17 $\beta$. The investigation of Scaramuzzi (1975) was extended in the present study to examine the effect of antibodies to oestradiol-17 $\beta$ on ovulation, oestrus and luteolysis in the intact ewe.

Four multiparous Romney ewes which had displayed 3 previous oestrous cycles of normal length ( $17 \pm 0.5$ days) were run with a vasectomized marker ram and checked for oestrus twice daily. Two of the ewes were injected i.v. with oestradiol-17 $\beta$ antiplasma $(15 \mathrm{ml})$, twice daily from Days 13-17 of the cycle. The two control ewes received a similar volume of plasma from an ovariectomized ewe. Blood was withdrawn from an indwelling silastic cannula daily for 2 days before and 6 days after treatment, and twice daily during passive immunization. Plasma was stored at $-20^{\circ} \mathrm{C}$ until analysis. All ewes were killed 6 days after the end of treatment and the ovaries were examined.

Pooled plasma of two consecutive bleedings from one ewe immunized against oestradiol-17 $\beta-6$ bovine serum albumin was used as the source of antiplasma (Peterson, Fairclough \& Smith, 1975). The titre of this antiplasma, defined as the dilution of plasma needed to achieve $50 \%$ binding of tritiated oestradiol-17 $\beta$, was $1: 8000$. The cross-reactions of the pooled antiplasma with oestrone and oestradiol- $17 \alpha$ were $3 \%$ and $0.9 \%$ respectively, but this specificity, as defined by Abraham (1969), may not necessarily reflect the binding characteristics of the antibodies in vivo.

Plasma progesterone and oestradiol-17 $\beta$ concentrations were determined by specific radioimmunoassays (Fairclough, Hunter \& Welch, 1975; Peterson Hunter, Welch \& Fairclough, 1975), except that for the oestrogen assay the chromatography step was omitted. The proportions of free to bound oestradiol-17 $\beta$ in the plasma of the treated and control ewes were determined by dialysing a $1: 50$ dilution of the plasma samples in $0.05 \mathrm{M}$-phosphate buffer $(\mathrm{pH} \mathrm{7.4)}$ against an outside buffer solution containing $0.07 \mathrm{nCi}\left[6,7-{ }^{3} \mathrm{H}\right]$ oestradiol-17 $\beta$ (sp. act. $45 \mathrm{Ci} / \mathrm{mmol}$ ).

Changes in the plasma concentrations of progesterone and oestradiol-17 $\beta$ in the control ewes (Text-fig. 1a) were comparable with those reported by Obst, Seamark \& Brown (1971) and Terqui, Dray \& Cotta (1973). Although the hormone pattern for total oestradiol-17 $\beta$ concentrations in the treated ewes was similar to that of the control ewes, the levels during and after immunization were greater (Text-fig. 1b). There was, however, a substantial reduction in free oestradiol-17 $\beta$, the $\%$ free falling from $5-8 \%$ before treatment to $0.2-0.05 \%$ during passive immunization.

Luteal regression, as indicated by a fall in progesterone levels, occurred at the expected time despite the low levels of free oestradiol-17 $\beta$ over the preceding $48-72 \mathrm{hr}$. The treated ewes failed to display oestrus and the absence of a newly formed CL indicated that ovulation was also blocked. 

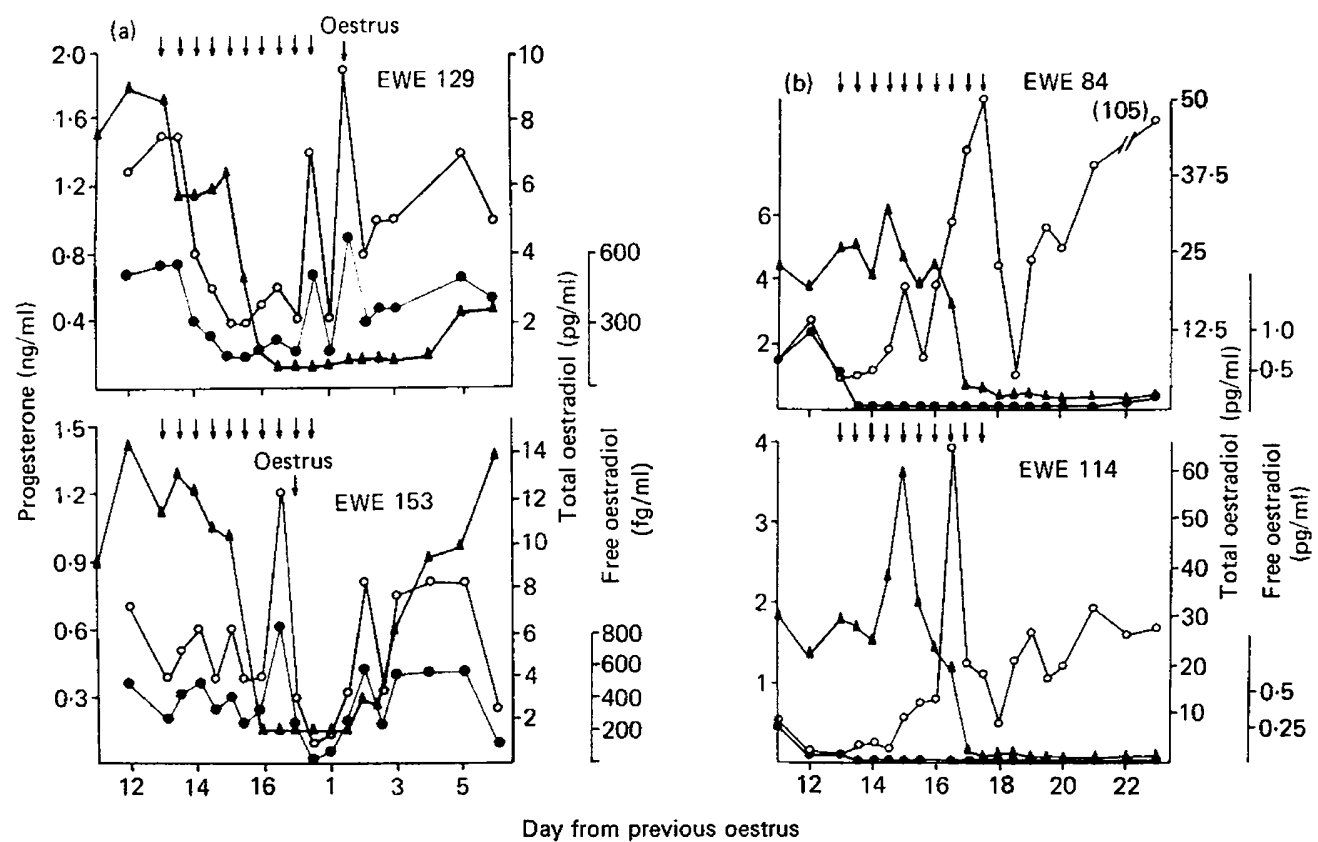

Text-fig. 1. Changes in plasma concentrations of progesterone $(\Delta)$ and free $(\bullet)$ and total $(0)$ oestradiol-17 $\beta$ in (a) control ewes about the time of oestrus, and (b) ewes passively immunized against oestradiol-17 $\beta$. The arrows indicate the times of injection of plasma from an ovariectomized ewe or of antiplasma to oestradiol-17 $\beta$.

At autopsy Ewe 129 possessed 1 large (10-15 mm diameter) CL and 3 small $(<2 \mathrm{~mm})$ follicles in the right ovary and 1 small CL and 2 small follicles in the left ovary. The other control ewe (No. 153) had a regressed CL and 3 small follicles in the right ovary and 2 large CL and 3 medium (2-5 mm) follicles in the left ovary. Each treated ewe had a regressed CL in the left ovary; Ewe 114 had 2 large follicles in the right ovary and Ewe 84 had 3 medium follicles in the right ovary and 2 large follicles in the left ovary.

The elevated total oestradiol-17 $\beta$ levels after immunization may be due to a decrease in the rate of catabolism of oestradiol-17 $\beta$ (Longscope, 1970) and to an increase in gonadotrophic stimulation in response to the depressed free oestradiol-17 $\beta$ levels. Elevated plasma LH concentrations in the ewe occur after passive (Ekre, 1973) and active (Pant \& Rawlings, 1973) immunization against oestradiol$17 \beta$, indicating that luteolysis in the passively immunized ewe is not a consequence of withdrawal of LH support.

Our results confirm the view that a preovulatory rise in free oestradiol-17 $\beta$ concentrations is necessary for behavioural oestrus and ovulation in the ewe. The regression of the CL in the treated ewes, despite the marked reduction in free oestradiol-17 $\beta$ concentrations, suggests, however, that oestradiol-17 $\beta$ does not play an essential role in luteolysis. This latter finding must however be interpreted with caution. It is possible that oestrogen produced earlier in the cycle may have been involved in the luteolysis and that treatment was begun too late, but similar results were obtained in a more recent experiment in which oestradiol-17 $\beta$ antiplasma was administered to ewes from Days 9-17 of the cycle (Fairclough, Smith, Peterson \& McGowan, 1976). It is also possible that the oestrogenic activity was not completely neutralized by the antiplasma treatment. Studies in rats have shown that oestrogen antibodies are capable of inhibiting the normal response which follows administration of oestradiol-17 $\beta$, although the oestradiol-17 $\beta$ effect could not be completely suppressed even with large amounts of antisera (Ferin et al., 1968). This suggests that immunization may not completely inhibit all the biological effects of hormones. Because the affinity constants of the oestrogen antibodies and the uterine receptor sites are comparable, the high-affinity uterine receptor proteins may compete for the antibody-bound oestradiol-17 $\beta$. An unequivocal interpretation of our results must 
therefore await an investigation of the effect of oestrogen antibodies on the dynamics of steroid movement from plasma to the high-affinity uterine binding sites.

We thank Mr H. Drost for care of the animals and Ms Tricia Woolford and Jewel Jackson for excellent technical assistance. A.J.P. is a recipient of a New Zealand National Advisory Research Council Post-Doctoral Fellowship.

\section{References}

ABRAHAM, G.E. (1969) Solid-phase radioimmunoassay of estradiol-173. J. clin. Endocr. Metab. 29, 866-870.

Barcikowski, B., Carlson, J.C., Wilson, L. \& McCracken, J.A. (1974) The effect of endogenous and exogenous estradiol-17 $\beta$ on the release of prostaglandin $F_{2 \alpha}$ from the ovine uterus. Endocrinology 95, 1340-1349.

EKRE, C. (1973) Some effects of progestens, estrogens and anti-LH and anti-estradiol sera on corpus luteum function and other reproductive processes in the ewe. Ph.D. thesis, Utah State University, Utah.

Fairclough, R.J., Hunter, J.T. \& Welch, R.A.S. (1975) Peripheral plasma progesterone and uteroovarian prostaglandin $F$ concentrations in the cow around parturition. Prostaglandins 9, 901-914.

Fairclough, R.J., Smith, J.F., Peterson, A.J. \& McGowan, L.T. (1976) The effect of oestradiol-17 $\beta$ progesterone and prostaglandin F-2 $\alpha$ antiplasma on luteal function in the ewe. J. Reprod. Fert. 46, 523524.

Ferin, M., Zimmering, P.E., Lieberman, S. \& Vande WIELE, R.I. (1968) Inactivation of the biological effects of exogenous and endogenous estrogens by antibodies to $17 \beta$-estradiol. Endocrinology 83, 565571.

LONGSCOPE, C, (1970) The use of antibodies as a tool in studies in reproductive physiology. In Immunological Methods in Steroid Determination, pp. 222-240.
Eds F. G. Peron \& B V. Caldwell. AppletonCentury-Crofts, New York.

Obst, J.M., Seamark, R.F. \& Brown, J.M. (1971) Application of a competitive protein-binding assay for oestrogens to the study of ovarian function in sheep. J. Reprod. Fert. 24, 140.

Pant, H.C. \& Rawlings, N.C. (1973) The effect of active immunization against oestradiol-17 $\beta$ on plasma gonadotrophin concentrations in sheep. J. Reprod. Fert. 35, 610-611.

Peterson, A.J., Fairclough, R.J. \& SMITh, J.F. (1975) Radioimmunoassay of estradiol-17 $\beta$ in bovine peripheral plasma with and without chromatography. Steroids 25, 487-496.

Peterson, A.J., Hunter, J.T., Welch, R.A.S. \& FairClough, R.J. (1975) Oestrogens in bovine fetal and maternal plasma near term. J. Reprod. Fert. 43, 179-181.

ROBERTSON, H.A. (1969) The endogenous control of estrus and ovulation in sheep, cattie and swine. Vitams Horm. 27, 91-130.

ScaramuzzI, R.J. (1975) Inhibition of oestrous behaviour in ewes by passive immunization against oestradiol-17ß.J. Reprod. Fert. 42, 145-148.

Terqui, M., Dray, F. \& CotTa, J. (1973) Variations de la concentration de l'oestradiol-17 $\beta$ dans le sang périphérique de la Brebis au cours du cycle oestral. C. r. hebd. Séanc. Acad. Sci., Paris 277, 1795-1798.

Received 17 November 1975 